\title{
Improvement in broiler performance by feeding a nutrient-dense diet after a mild feed restriction
}

\author{
Mejora del rendimiento en pollos de engorde mediante una dieta rica en nutrientes tras una ligera \\ restricción alimenticia
}

\section{Melhoria dos rendimentos de frangos de corte de uma dieta rica em nutrientes após uma restrição ligeira}

\author{
Mohammad Hadaeghi ${ }^{1}$ iD; Carmen Avilés-Ramírez ${ }^{2}$ iD; Alireza Seidavi ${ }^{*}$ iD; Leila Asadpour $^{3}$ iD; \\ Nieves Núñez-Sánchez ${ }^{4}$; ; Andrés L Martínez-Marín 4 (D).
}

\author{
${ }^{1}$ Department of Animal Science, Rasht Branch, Islamic Azad University, Rasht 41335-3516, Iran. \\ ${ }^{2}$ Departamento de Bromatología y Tecnología de los Alimentos, Universidad de Córdoba, Campus de Rabanales, 14071. Córdoba, España. \\ ${ }^{3}$ Department of Biology, Rasht Branch, Islamic Azad University, Rasht 41335-3516, Iran. \\ ${ }^{4}$ Departamento de Producción Animal, Universidad de Córdoba, Campus de Rabanales, 14071. Córdoba, España.
}

To cite this article:

Hadaeghi M, Avilés-Ramírez C, Seidavi A, Asadpour L, Núñez-Sánchez N, Martínez-Marín AL. Improvement in broiler performance by feeding a nutrient-dense diet after a mild feed restriction. Rev Colomb Cienc Pecu 2021; 34(3): 189-199. DOI: https://doi.org/10.17533/udea.rccp.v34n3a02

\begin{abstract}
Background: The use of early nutrient-restriction programs in broilers can prevent complications such as increased body fat deposition and its consequences. However, feed restriction not always gives the expected results. Objective: To assess the effect of two levels of feed restriction followed by a re-alimentation period with five increasing nutrient levels on growth performance and immune response of broiler chickens. Methods: A total of 330 animals were used. The treatments were: 25 (T25) and 35\% (T35) quantitative feed restriction during the starting period, and 0, 2.5, 5, 7.5, 10, and 15\% increased energy and protein contents during the growing and finishing periods. Results: For all the T25 treatments, except for T25-0, feed intake (FI) and body weight gain (BWG) were higher, and feed conversion rate (FCR) was lower ( $\mathrm{p}<0.05)$ compared to the control treatment. In that group, the response of FI and BWG to the increased nutrient density was mostly quadratic ( $<<0.001$ ), whereas that of FCR was linear $(\mathrm{p}<0.001)$. The FI and BWG results were less homogeneous in the T35 treatments, but FCR was lower compared to the control treatment $(p<0.05)$ in all of them. The FCR showed no differences $(p>0.05)$ between treatments during the finishing period. Conclusion: Feeding a nutrient-dense diet after a period of mild feed restriction gives the best
\end{abstract}

Received: August 4, 2018; accepted: August 3, 2020

*Corresponding author. Rasht 41335-3516, Iran. Tel.: +989113313073. Fax: 981314224069.

Email: alirezaseidavi@iaurasht.ac.ir 
results, while increasing nutrient density after a more severe feed restriction does not improve productive results compared to a standard diet. Carcass traits and immune function were not affected by restriction level or nutrient density.

Keywords: broilers; broiler chicken; catch-up growth; compensatory growth; feed restriction; feeding; immunity; nutrientdense diet; nutrition; poultry; growth performance.

\section{Resumen}

Antecedentes: El uso de programas de restricción alimenticia temprana en pollos de engorde puede prevenir el incremento de la deposición de grasa corporal y sus consecuencias. Sin embargo, la restricción alimenticia no proporciona siempre los resultados esperados. Objetivo: Investigar los efectos de dos niveles de restricción alimenticia seguida por un período de realimentación con cinco niveles crecientes de nutrientes sobre el rendimiento productivo y la respuesta inmune de pollos de engorde. Métodos: Se utilizaron 330 animales. Los tratamientos fueron: restricción cuantitativa del 25 (T25) y del 35\% (T35) durante el periodo de iniciación y aumento de la energía y contenido proteico de la dieta del $0,2,5,5,7,5,10$ y $15 \%$ durante los periodos de crecimiento y finalización. Resultados: Para casi todos los T25 el consumo de alimento (FI) y el aumento de peso corporal (BWG) fueron mayores y el índice de conversión (FCR) menor $(\mathrm{p}<0,05)$ en comparación con el control. La respuesta del FI y el BWG al aumento de la densidad de nutrientes en este grupo fue mayoritariamente cuadrática $(\mathrm{p}<0,001)$, mientras que en el caso del FCR fue lineal $(p<0,001)$. Los resultados del FI y el BWG fueron menos homogéneos en los T35, pero el FCR fue menor que en el control $(p<0,05)$. El FCR no mostró diferencias $(p>0,05)$ entre tratamientos durante el periodo de acabado. Conclusión: La alimentación con una dieta rica en nutrientes después una restricción ligera proporciona los mejores resultados, mientras que el incremento de la densidad de la dieta después de una restricción severa no mejora los resultados productivos en comparación con una dieta estándar. Las características de la canal y la respuesta inmune no se vieron afectadas por el nivel de restricción o la densidad de nutrientes de la dieta.

Palabras clave: alimentación; avicultura; crecimiento compensatorio; dieta densa; inmunidad; nutrición; pollos; pollos de engorde; restricción alimenticia; rendimiento productivo.

\section{Resumo}

Antecedentes: O uso de programas de restrição precoce de nutrientes em frangos de corte tem o potencial de prevenir complicações como o aumento da deposição de gordura corporal e suas consequências. No entanto, a restrição alimentar nem sempre dá os resultados esperados. Objetivo: Investigar os efeitos de dois níveis de restrição alimentar seguidos de um período de re-alimentação com cinco níveis crescentes de nutrientes no rendimento produtivo e na resposta imune de frangos de corte. Métodos: Foram utilizados 330 animais. Os tratamentos foram: restrição quantitativa de 25 (T25) e 35\% (T35) durante o período inicial e aumento do conteúdo energético e proteico da dieta de $0,2,5,5,7,5,10$ e $15 \%$ durante os períodos de crescimento e finalização. Resultados: Para todos os tratamentos T25, menos para T25-0, consumo de ração (FI) e ganho de peso corporal (BWG) foram maiores e a taxa de conversão $(\mathrm{FCR})$ foi menor $(\mathrm{p}<0,05)$ o controle. A resposta do FI e do BWG ao aumento da densidade de nutrientes nesse grupo foi principalmente quadrática ( $\mathrm{p}<0,001)$, enquanto no caso da FCR foi linear ( $<<0,001)$. Os resultados do FI e do BWG foram menos homogêneos nos tratamentos T35, mas o FCR foi menor que no tratamento controle $(p<0,05)$. O FCR não apresentou diferenças $(p>0,05)$ entre os tratamentos durante o período de terminação. Nenhuma tendência clara foi observada no peso relativo dos órgãos linfóides ou na resposta imune devido aos tratamentos testados. Conclusão: A alimentação de uma dieta rica em nutrientes após um período de restrição leve proporcionou os melhores resultados, enquanto o aumento da densidade de nutrientes na dieta após uma restrição severa não melhorou os resultados produtivos em comparação com uma dieta padrão.

Palavras-chave: alimentação; avicultura; crescimento compensatório; dieta rica em nutrientes; frangos de corte; imunidade; nutrição; restrição alimentar; resultados produtivos. 


\section{Introduction}

The spectacular growth performance experienced by broiler chickens over the last decades has been accompanied by metabolic disorders, low resistance to diseases, and increased deposition of body fat (Leeson and Zubair, 1997). This last condition in broiler chickens is inefficient in terms of energy metabolism and represents an economic loss for the producers (Tůmová and Teimouri, 2010). Growth rate and body composition throughout the lifecycle of animals are determined, among others, by feed consumption (Richards, 2003). The use of early nutrient-restriction programs has the potential to prevent complications such as increased body fat deposition and its consequences (i.e., reproductive failure, sudden death syndrome, cardiovascular disorders, impaired thermoregulation, and decreased immunity) (Sahraei, 2012; Zubair, 1996). Those feeding programs rely on the phenomenon called compensatory growth. Compensatory growth occurs when chickens whose growth has been retarded by dietary restriction grow faster than animals of the same age with no prior restriction (Lippens et al., 2000).

A wide range of alternatives have been used to induce this mechanism of growth regulation. Wilson and Osbourn (1960) concluded that compensatory growth after undernutrition was affected by the duration and timing of undernutrition, the nature and severity of undernutrition, genetic factors like sex, bird strain, and re-alimentation condition (Zubair, 1996). However, very few studies have considered the effect of nutrient concentration of the diets used during the refeeding period (Rahimi, 2015; Taschetto et al., 2012).

Feed restriction not always gives the expected results, and the best feed conversion does not guarantee the best economic efficiency (Jahanpour et al., 2015; Eila et al., 2011; Novele et al., 2008). Therefore, the present work aimed to understand the interaction between restriction level during the starter period and nutrient content of the diet in the growing and finishing periods. This study was conducted to assess the effect of two levels of feed restriction followed by a re-alimentation period with five increasing levels of nutrients on the growth performance and immune response of broiler chickens.

\section{Materials and Methods}

\section{Ethical considerations}

Use and care of birds and procedures in this study were approved by the Islamic Azad University Ethics Committee (protocol number 17.16.4.16987/2014).

\section{Animals}

Before starting the trial, the research facility was thoroughly cleaned and disinfected. Three hundred and thirty (one-day-old) male chickens of Ross 308 strain (Aviagen, Newbridge, UK) purchased from a commercial hatchery were used. The broiler chicks were placed in $1.5 \times$ $1.0 \mathrm{~m}$ cages, which floor was covered with shredded paper. Each cage was equipped with a pan feeder and a manual drinker. The research facility was an open-sided poultry barn equipped with thermostatically controlled curtains, thermostatically controlled gasoline rocket heaters, overhead sprinklers, wallmounted fans at both ends of the barn, and fluorescent tubes in ceiling fixtures. Ambient temperature was set at $32{ }^{\circ} \mathrm{C}$ for placement and then decreased gradually to achieve $24^{\circ} \mathrm{C}$ from week 3 onwards. Lighting was constant on day 1. From day 2 to the end of the study, the light regime was 23L:1D.

The experiment lasted 42 days. The feeding program consisted of a starter diet until chicks were 14 days old, followed by a grower diet up to 28 days of age, and then a finisher diet until the end of the experiment. The diets were formulated according to a standard commercial program (Table 1).

Chicks were randomly assigned into one of 11 treatments, including a control (Table 2), each of them having five replicates; thus there were a total of 55 groups of six birds. 
Table 1. Experimental diets fed to broiler chickens.

\begin{tabular}{|c|c|c|c|c|c|c|c|c|c|c|c|}
\hline & & & & Grower & & & & & inisher & & \\
\hline & Starter & 0 & $+2.5 \%$ & $+5 \%$ & $+7.5 \%$ & $+10 \%$ & 0 & $+2.5 \%$ & $+5 \%$ & $+7.5 \%$ & $+10 \%$ \\
\hline Ingredients, $\mathrm{g} / \mathrm{kg}$ & & & & & & & & & & & \\
\hline Corn & 55.91 & 24.18 & 25.74 & 49.84 & 54.32 & 51.16 & 38.17 & 52.88 & 57.00 & 58.40 & 57.90 \\
\hline Wheat & & 40.00 & 34.28 & 9.00 & 1.00 & & 27.75 & 11.99 & 3.50 & 1.74 & \\
\hline Corn gluten meal & & & 1.00 & 3.70 & 4.05 & 3.08 & 1.03 & 1.83 & 1.30 & 10.00 & 12.35 \\
\hline Soybean meal 47 & 37.07 & 28.54 & 30.00 & 28.47 & 24.52 & 22.70 & 22.46 & 20.75 & 23.95 & 18.26 & 17.00 \\
\hline Roasted soybeans & & & & & 7.00 & 13.00 & & & & & \\
\hline Meat meal & & 2.00 & 2.00 & 2.00 & 2.00 & 2.00 & 2.00 & 4.10 & 4.00 & & \\
\hline Soybean oil & 2.78 & 2.31 & 4.00 & 3.90 & 4.00 & 4.97 & 4.47 & 4.90 & 6.64 & 6.70 & 7.79 \\
\hline Calcium carbonate & 1.27 & 1.00 & 1.00 & 1.01 & 1.00 & 1.00 & 1.93 & 1.74 & 1.69 & 2.00 & 2.00 \\
\hline Dicalcium phosphate & 1.90 & 0.65 & 0.65 & 0.69 & 0.68 & 0.68 & 1.18 & 0.90 & 1.00 & 1.67 & 1.71 \\
\hline Salt & 0.25 & 0.21 & 0.21 & 0.20 & 0.20 & 0.20 & 0.14 & 0.14 & 0.13 & 0.20 & 0.20 \\
\hline Sodium bicarbonate & 0.15 & 0.06 & 0.05 & 0.10 & 0.12 & 0.12 & 0.21 & 0.10 & 0.20 & 0.20 & 0.20 \\
\hline DL-Methionine & 0.13 & 0.26 & 0.28 & 0.24 & 0.25 & 0.25 & 0.09 & 0.08 & 0.07 & 0.02 & 0.02 \\
\hline L-Lysine & 0.04 & 0.21 & 0.21 & 0.29 & 0.30 & 0.28 & 0.07 & 0.09 & 0.02 & 0.31 & 0.33 \\
\hline L-Threonine & & 0.08 & 0.08 & 0.06 & 0.06 & 0.06 & & & & & \\
\hline Vitamin-mineral premix ${ }^{2}$ & 0.50 & 0.50 & 0.50 & 0.50 & 0.50 & 0.50 & 0.50 & 0.50 & 0.50 & 0.50 & 0.50 \\
\hline Nutrient composition & & & & & & & & & & & \\
\hline $\begin{array}{l}\text { Metabolizable energy, MJ/ } \\
\mathrm{kg}\end{array}$ & 12.4 & 12.5 & 12.9 & 13.1 & 13.4 & 13.7 & 13.1 & 13.4 & 13.8 & 14.1 & 14.4 \\
\hline Crude protein, $\%$ & 22.0 & 20.9 & 21.8 & 22.0 & 22.5 & 22.9 & 18.3 & 18.7 & 19.2 & 19.7 & 20.3 \\
\hline Lysine, $\%$ & 1.23 & 1.22 & 1.25 & 1.28 & 1.32 & 1.37 & 0.94 & 0.96 & 0.97 & 1.01 & 1.01 \\
\hline Threonine, $\%$ & 0.47 & 0.57 & 0.60 & 0.59 & 0.61 & 0.61 & 0.38 & 0.38 & 0.38 & 0.39 & 0.41 \\
\hline Methionine, $\%$ & 0.84 & 0.83 & 0.86 & 0.87 & 0.89 & 0.91 & 0.66 & 0.68 & 0.72 & 0.72 & 0.73 \\
\hline Tryptophan, \% & 0.27 & 0.25 & 0.26 & 0.24 & 0.24 & 0.26 & 0.21 & 0.20 & 0.21 & 0.19 & 0.18 \\
\hline Calcium, $\%$ & 1.06 & 0.79 & 0.79 & 0.80 & 0.80 & 0.81 & 1.26 & 1.26 & 1.26 & 1.24 & 1.25 \\
\hline Total phosphorus, $\%$ & 0.72 & 0.56 & 0.56 & 0.56 & 0.56 & 0.56 & 0.62 & 0.63 & 0.65 & 0.62 & 0.62 \\
\hline
\end{tabular}

${ }^{1} 2.5,5,7.5,10$, and $15 \%$ increment of diet energy and protein concentrations over the control $(0 \%)$.

${ }^{2}$ Supplied per kilogram of feed - Vitamin A: 12,500 IU; vitamin D3: 1,250 IU; vitamin E: 18 IU; vitamin K3: $3.7 \mathrm{mg}$; thiamine: $1.8 \mathrm{mg}$; riboflavin: $6.6 \mathrm{mg}$; calcium pantothenate: $10 \mathrm{mg}$; niacin: $37.5 \mathrm{mg}$; pyridoxine: $32.5 \mathrm{mg}$; vitamin B12: $2.5 \mathrm{mg}$; Mn: 50 mg; Zn: 37.5 mg; Fe: 25 mg; Cu: 7.5 mg.

In treatments 2 to 11 , feed restriction consisted of a daily feed supply adjustment between 8 and 14 days of age proportional to feed intake of control chicks in the previous day ( 75 and $65 \%$ in T25- and T35- treatments, respectively). In those treatments, more energy and protein content (T25-2.5, T25-5, T25-7.5, T25-10, T35-2.5, T35-5, T35-7.5, T35-10) or not (T25-0 and T350 ) were supplied from day 15 onwards. Control broilers were fed ad libitum during the whole experimental period, while broilers in the other treatments were fed ad libitum before and after the feed restriction period. Body weight (BW) of the chicks and feed consumption were weekly recorded by cage, and body weight gain (BWG, $\mathrm{g} /$ period), feed intake (FI, g/period), and feed conversion ratio (FCR, feed to gain $\mathrm{g} / \mathrm{g}$ ) were determined. At the age of 42 days, after 4 hours of fasting for complete evacuation of the gut, five chickens per treatment (one from each replicate) 
that had weights closest to the mean weight for the cage were selected and euthanized by cervical dislocation (Leary et al., 2013). Birds were fully plucked by the dry plucking method, eviscerated, and weights of the organs related to the immune system were recorded.

Antibody production to different antigens was assessed during the experiment. First, the birds were vaccinated against influenza $\left(1^{\text {st }}\right.$ day of age $)$, infectious bronchitis ( $4^{\text {th }}$ and $17^{\text {th }}$ day of age), Newcastle disease ( $9^{\text {th }}$ and $16^{\text {th }}$ day of age $)$, and Gumboro disease $\left(14^{\text {th }}\right.$ and $23^{\text {rd }}$ day of age). The vaccines were provided by Razi Co. (Tehran, Iran). Additionally, birds were injected under the breast skin with $0.5 \mathrm{ml}$ of a $10 \%$ suspension in phosphate buffered saline of sheep red blood cells (SRBC) on the $22^{\text {nd }}$ and $29^{\text {th }}$ days of age. To determine the systemic antibody response, blood samples were collected from one chick per replicate via the wing vein on the 19 th and $26^{\text {th }}$ (Newcastle disease), $30^{\text {th }}$ and $40^{\text {th }}$ (influenza disease), and $29^{\text {th }}$ and $36^{\text {th }}$ (SRBC) days of age. Blood samples were processed and analyzed as described by Pourhossein et al. (2014). To determine antibody response to influenza and Newcastle disease, a hemagglutination inhibition assay was used. Total immunoglobulin (Ig) and immunoglobulin $\mathrm{G}$ (IgG) titers to SRBC were determined by hemagglutination assay; then, immunoglobulin $\mathrm{M}$ (IgM) titers to SRBC were calculated as the difference between total Ig and IgG titers.

\section{Statistical analysis}

The GLM procedure of SAS UE 3.5 (SAS Institute Inc., Cary, NC) was used for the analysis. The statistical model was Yijk $=\mu+\mathrm{Aj}+\mathrm{Bk}+$ $A B j k+$ eijk, where Yij is the dependent variable; $\mu$ represents the overall mean; $\mathrm{Aj}$ is the fixed effect of restriction; $\mathrm{Bk}$ is the fixed effect of diet nutrient density after restriction cessation; $A B j k$ is the interaction of both effects, and eijk is the residual error. The least square means in the treatments of the T25 and T35 groups were compared with those of the Control group by using Dunnet's test. The linear and quadratic responses to refeeding levels within each feed restriction group were investigated through polynomial contrasts with the CONTRAST option. Correlations between the percentage of carcass fat and plasma lipids were investigated with the SAS CORR procedure. Statistical significance was declared at $\mathrm{p}<0.05$.

\section{Results}

Mortality rate of broiler chickens was $0 \%$ in all the experimental treatments. In the results presented below, any significant differences at $p<0.05$ between the experimental treatments and thecontroltreatmentcorrespond to thesuperscripts A or B placed after the least squares mean in the tables. Growth performance traits during the different feeding periods are shown in Table 3.

Table 2. Dietary treatments during the experiment.

\begin{tabular}{lcc}
\hline Treatment & $\begin{array}{c}\text { Quantitative feed restriction relative to } \\
\text { control between } 8 \text { and 14 days of age }\end{array}$ & $\begin{array}{c}\text { Increase in dietary energy and protein } \\
\text { contents from day 15 onwards }\end{array}$ \\
\hline Control & $0 \%$ & $0 \%$ \\
T25-0 & $25 \%$ & $0 \%$ \\
T25-2.5 & $25 \%$ & $+2.5 \%$ \\
T25-5 & $25 \%$ & $+5 \%$ \\
T25-7.5 & $25 \%$ & $+7.5 \%$ \\
T25-10 & $25 \%$ & $+10 \%$ \\
T35-0 & $35 \%$ & $0 \%$ \\
T35-2.5 & $35 \%$ & $+2.5 \%$ \\
T35-5 & $35 \%$ & $+5 \%$ \\
T35-7.5 & $35 \%$ & $+7.5 \%$ \\
T35-10 & $35 \%$ & $+10 \%$ \\
\hline
\end{tabular}


As expected, there were no differences $(\mathrm{p}>0.05)$ in performance between treatments before the restriction period (1-7 d), but they were higher $(\mathrm{p}<0.05)$ in the control treatment during restriction. In the growing period, FI and BWG were higher, and FCR was lower $(\mathrm{p}<0.05)$ for all the T25 treatments, except for T25-0, compared with the control treatment, and the response of FI and BWG to increased nutrient density following feed restriction was mostly quadratic $(\mathrm{p}<0.001)$, whereas that of FCR was linear $(p<0.001)$. The FCR results were lower in all the T35 treatments compared to the control $(\mathrm{p}<0.05)$; however, FI and BWG results were more heterogeneous in the T35 treatments. Contrary to the T25 group, the observed improvement in FCR in the T35 group was more clearly related to an increased BWG without a concomitant increase in FI. During finishing, no differences ( $>0.05$ ) were observed in FCR between T25 and T35 compared to the control treatment. When the whole experimental period was considered, BWG was higher and FCR was lower $(p<0.05)$ in T25-5, T25-7.5 and T25-10 treatments compared to the control; those parameters showed an increasing and decreasing linear fashion $(p<0.01)$, respectively, as nutrient density increased. The T35 group did not show clear responses. The only significant effect was the lower FI and FCR $(\mathrm{p}<0.05)$ in the T35-7.5 treatment compared to the control.

Very few effects and no clear lineal or quadratic responses were observed in the weight of immune-related organs as a percentage of $\mathrm{BW}$, nor in the immune response to vaccines due to the treatments assayed (Table 4).

\section{Discussion}

Feed restriction programs in broilers are mainly intended to improve feed efficiency and decrease fat deposition without compromising the health status. Several reports have placed emphasis on quantitative feed restriction in the early stages of growth (Lippens et al., 2009; Mohebodini et al., 2009; Novele et al., 2009; Shabani et al., 2015) but few studies have investigated the effects of nutrient density of the diet after the feed restriction period (Giachetto et al., 2003; Leeson and Zubair, 1997; Rahimi et al., 2015; Santoso et al., 1995).

In the present study, the best FCR and highest BW at slaughter was observed in the T25 group compared to the control treatment, and the response was positively related to the nutrient density of the diet (Tables 2 and 4). Nevertheless, the T35 group showed full BW recovery at the end of the experimental period irrespective of nutrient density levels (Table 4), despite an 11\% $\mathrm{BW}$ reduction at the end of the restriction period compared to the control. These results agreed with Rosa et al. (2000), who indicated that the occurrence of compensatory growth in broilers could be compromised when weight losses are over $11-12 \%$. The occurrence of full BW recovery at slaughter age after quantitative feed restriction is contradictory (Jahanpour et al., 2015; Mohebodini et al., 2009; Saleh et al., 2005; Shabani et al., 2015), which might be explained by several factors, including severity, duration and timing of the restriction period, length of the refeeding period, and animal characteristics ( $\mathrm{Yu}$ and Robinson, 1992), as well as physical form of the feed (Lippens et al., 2009; Shabani et al., 2015). On the other hand, our results support that full BW recovery does not seem always to be related to better FCR as reported by Butzen et al. (2013) and Novele et al. (2009). Our results are mostly in agreement with those of Rahimi et al. (2015), who tested 15 and $30 \%$ quantitative feed restriction between 8 and 14 days of age and higher energy and protein diets $(5,10$, and $15 \%)$ in the feed restricted groups afterward. It is noteworthy that the average productive results of the T35 group in the present work were similar to those of the control treatment. In contrast, the T30 group of Rahimi et al. (2015) performed better than their control treatment. This point suggests a possible threshold in the quantitative feed restriction of broilers above which no improvement of productive results occurs. Moreover, in the T25 group, FCR improvements were only observed in the T25-5, T25-7.5, and T25-10 treatments, indicating that a minimum increase of dietary energy and protein density is needed during the refeeding period to achieve the best results. 
Table 3. Feed intake (FI), body weight gain (BWG) and feed conversion rate (FCR) of broilers raised under a normal feeding program (control), or two levels of quantitative feed restriction ( 25 and $35 \%$ ) between 8 and 14 days of age followed by refeeding energy and protein dense diets $(0,2.5,5,7.5$ and $10 \%$ over the control diet) from 15 to 42 days of age.

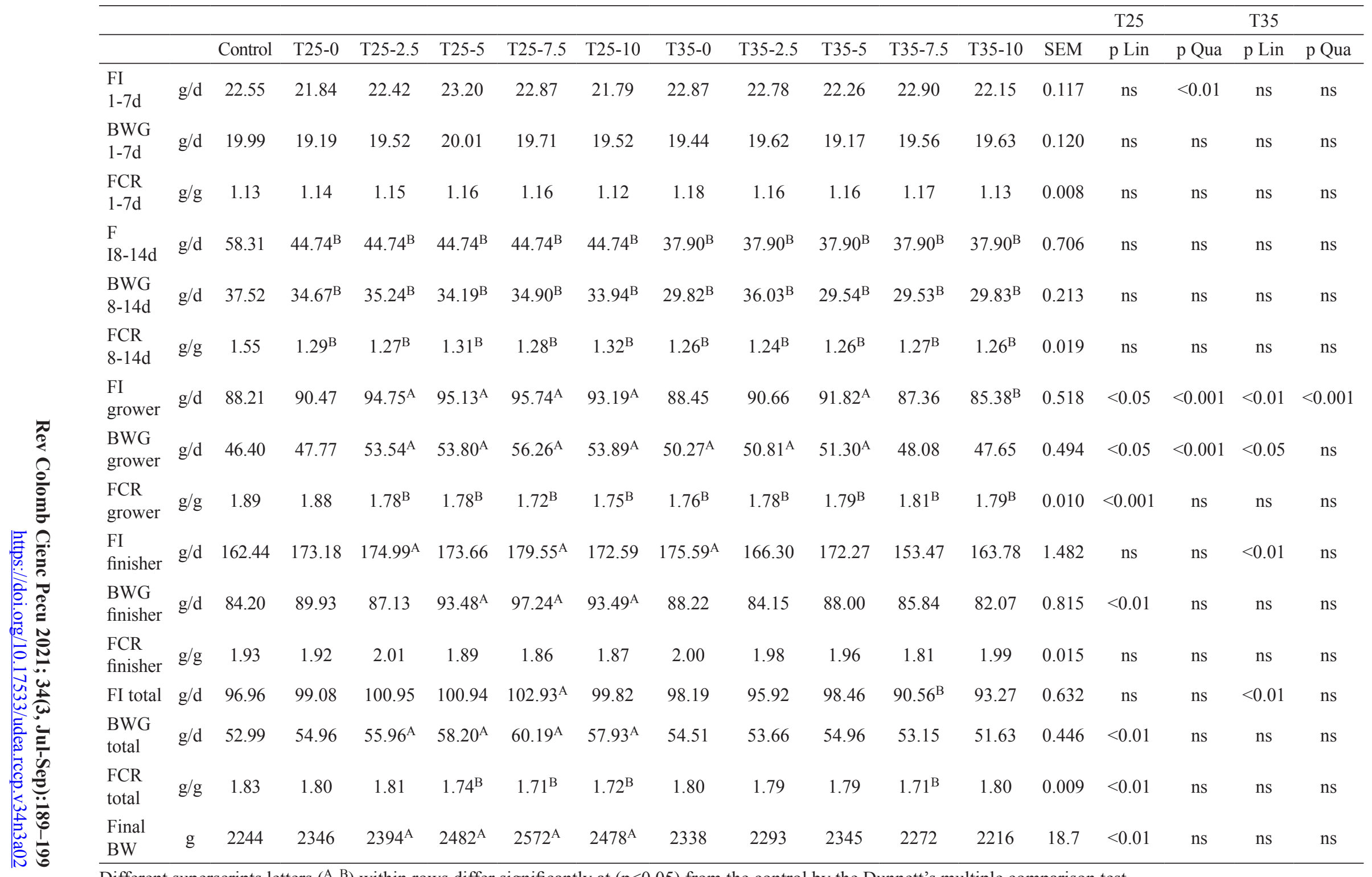

Different superscripts letters $(\mathrm{A}, \mathrm{B})$ within rows differ significantly at $(\mathrm{p}<0.05)$ from the control by the Dunnett's multiple comparison test.

ns: not significant. 
Table 4. Immune-related organ weight and immune response after vaccination or injection of sheep red blood cells (SRBC) in broilers raised under a normal feeding program (control), or two levels of quantitative feed restriction ( 25 and 35\%) between 8 and 14 days of age followed by refeeding high energy and protein-dense diets $(0,2.5,5,7.5$ and $10 \%$ over the control diet) from 15 to 42 days of age.

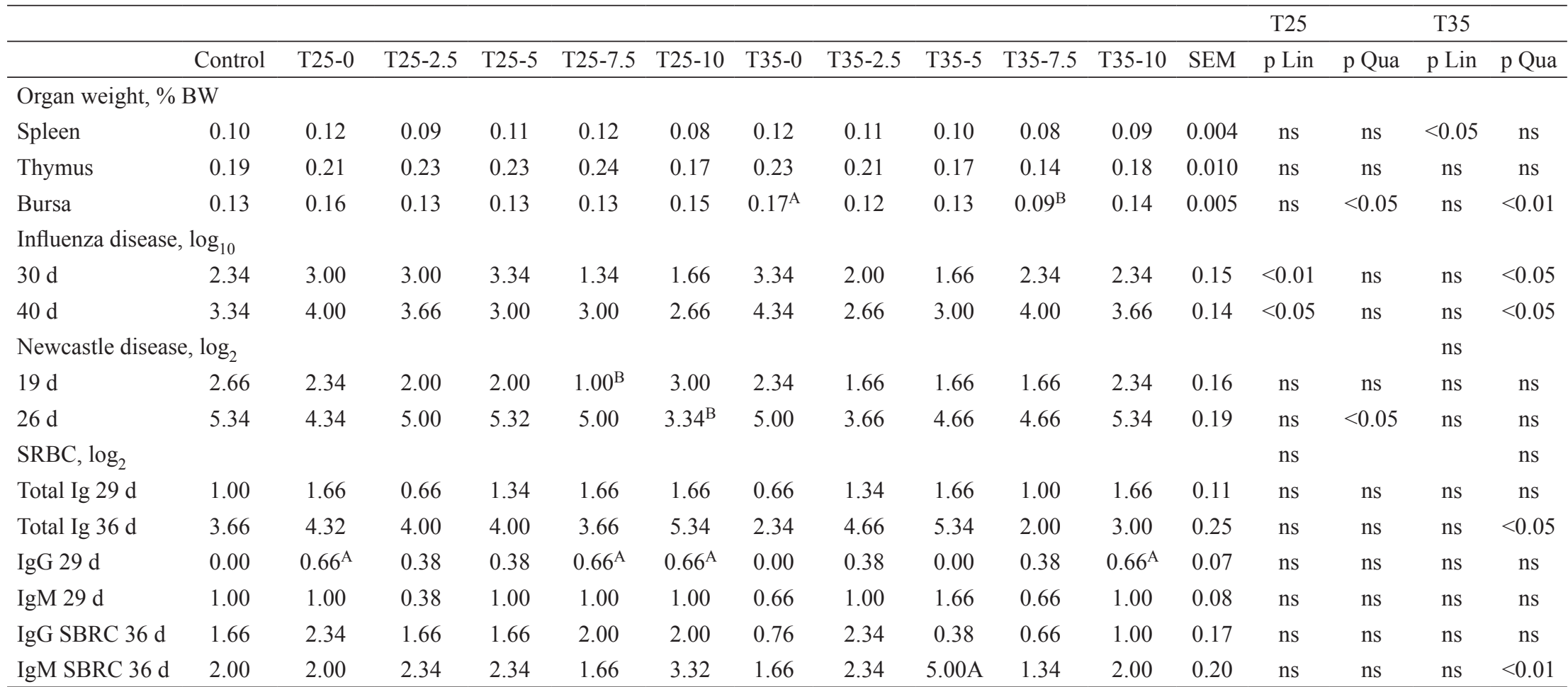

Different superscripts letters $(\mathrm{A}, \mathrm{B})$ within rows differ significantly at $(\mathrm{p}<0.05)$ from the control by the Dunnett's multiple comparison test.

ns: not significant. 
In this regard, energy level during refeeding seems to be more important than protein content, providing that enough protein is supplied (Leeson and Zubair, 1997; Santoso et al., 1995).

Several researchers have reported the effects of feed restriction on immune-related organs and immune response of broilers (Jahanpour et al., 2015; Mahmood et al., 2007; Onbasilar et al., 2009), but information on the effects of feeding broilers nutrient dense diets following a feed restriction period on immune-related organ weight and immune response is scarce (Rahimi et al., 2015). According to the early results of Klassing (1988), it might be expected that nutritional status of the chicks could affect the immune function. However, in the present study, no remarkable effects of neither a period of feed restriction nor feeding nutrient dense diets in the re-alimentation period were observed (Table 4), which agrees with the results of Jahanpour et al. (2015), Onbasilar et al. (2009) and Rahimi et al. (2015).

Summarizing, growth performance during the overall feeding period suggests that feeding a nutrient dense diet after a period of mild feed restriction (T25) gives the best results, while increasing nutrient density of the diet after a more severe feed restriction (T35) does not improve productive results compared to a standard diet. Carcass traits and immune function are not affected by the restriction level or nutrient density during the re-alimentation period under the conditions assayed.

\section{Declarations}

\section{Acknowledgements}

The Animal Production Department of the University of Cordoba (Spain) is kindly acknowledged.

\section{Funding}

This work was supported by the Rasht Branch, Islamic Azad University, under grant number 17.16.4.8774.

\section{Conflicts of interest}

The authors declare they have no conflicts of interest with regard to the work presented in this report.

\section{Author contribution}

Alireza Seidavi and Mohammad Hadaeghi designed the experiment, and Mohammad Hadaeghi, Alireza Seidavi and Laila Asadpour carried it out. Andrés L Martínez-Marín performed the statistical analysis. Andrés L Martínez-Marín and Carmen Avilés-Ramírez prepared the manuscript with contributions from all the co-authors.

\section{References}

Butzen FM, Ribeiro AML, Vieira MM, Kessler AM, Dadalt JC, Della MP. Early feed restriction in broilers. I- Performance, body fraction weights, and meat quality. J Appl Poult Res 2013; 22(2): 251-259. DOI: https://doi.org/10.3382/japr.2012-00639

Eila N, Lavvaf AG, Farahvash T. Comparison of different feed restriction methods on growth performance of broilers. Res Opin Anim Vet Sci 2011; 1(10): 686-688. DOI: http://dx.doi.org/10.1590/S1516-635X2010000300006

Giachetto PF, Guerreiro EN, Ferro JA, Ferro MIT, Furlan RL, Macari M. Performance and hormonal profile in broiler chickens fed with different energy levels during post restriction period. Pes Agropec Bras 2003; 38(6): 697-702. DOI: http://dx.doi.org/10.1590/S0100-204X2003000600005

Jahanpour H, Seidavi A, Qotbi AAA, Van Den Hoven R, Silva SR, Laudadio V, Tufarelli V. Effects of the level and duration of feeding restriction on carcass components of broilers. Arch Anim Breed 2015; 58: 99-105. DOI: http://dx.doi.org/10.5194/aab-58-99-2015

Klasing KC. Influence of acute feed deprivation or excess feed intake on immune competence of broiler chickens. Poult Sci 1988; 67: 626-631. DOI: https://doi.org/10.3382/ps.0670626 
Leary S, Underwood W, Anthony R, Cartner, S, Corey D, Grandin T, Greenacre C, GwaltneyBrant S, McCrackin MA, Meyer R, Miller D, Shearer J, Yanong R. AVMA Guidelines for the euthanasia of animals: 2013 Edition. Schaumburg (IL): American Veterinary Medical Association; 2013. p. 62-63.

Leeson S, Zubair AK. Nutrition of the broiler chicken around the period of compensatory growth. Poult Sci 1997; 76: 992-999. DOI: https://doi.org/10.1093/ps/76.7.992

Lippens M, Delezie E, Maertens L, Huyghebaert $\mathrm{G}$. Influence of feed texture and early quantitative feed restriction on performance, growth development and carcass composition of two broiler strains. Eur Poult Sci 2009; 73(1): 29-40.

Mahmood S, Mehmood S, Ahmad F, Masood A, Kausar R. Effects of feed restriction during starter phase on subsequent growth performance, dressing percentage, relative organ weights and immune response of broilers. Pak Vet J 2007; 27(3): 137-141.

Mohebodini H, Dastar B, Shams Sharg M, Zerehdaran S. The comparison of early feed restriction and meal feeding on performance, carcass characteristics and blood constituents of broiler chickens. J Anim Vet Adv 2009; 8(10): 2069-2074. DOI: http://doi=javaa.2009.2069.2074

Novele DJ, Ng'ambi JW, Norris D, Mbajiorgu CA. Effect of sex, level and period of feed restriction during the starter stage on productivity and carcass characteristics of Ross 308 broiler chickens in South Africa. Int J Poult Sci 2008; 7(6): 530-537. DOI: https://doi.org/10.3923/ijps.2008.530.537

Onbasilar EE, Yalçin S, Torlak E, Özdemir P. Effects of early feed restriction on live performance, carcass characteristics, meat and liver composition, some blood parameters, heterophil-lymphocyte ratio, antibody production and tonic immobility duration. Trop Anim Health Prod 2009; 41(7): 1513-1519. DOI: https://doi.org/10.1007/s11250-009-9341-8
Rahimi S, Seidavi A, Sahraei M, Blanco FP, Schiavone A, Martínez Marín AL. Effects of feed restriction and diet nutrient density during re-alimentation on growth performance, carcass traits, organ weight, blood parameters and the immune response of broilers. Ital J Anim Sci 2015; 14(3): 583-590. DOI: https://doi.org/10.4081/ijas.2015.4037

Richards MP. Genetic regulation of feed intake and energy balance in poultry. Poult Sci 2003; 82(6): 907-916. DOI: https://doi.org/10.1093/ps/82.6.907

Rosa PS, Ávila VS, Jaenisch FRF. Restrição alimentar em frangos de corte; como explorar suas potencialidades. Embrapa Suínos e Aves 2000; 250: $1-4$.

Sahraei M. Feed restriction in broiler chicken production:Areview.GlobVet2012;8(5):449-458. DOI: https://doi.org/10.2298/BAH1202333S

Saleh EA, Watkins SE, Waldroup AL, Waldroup PW. Effects of early quantitative feed restriction on live performance and carcass composition of male broilers grown for further processing. J App Poult Res 2005; 14(1): 87-93. DOI: https://doi.org/10.1093/japr/14.1.87

Santoso U, Tanaka K, Ohtani S. Early skip-a-day feeding of female broiler chicks fed high-protein re-alimentation diets. Performance and body composition. Poult Sci 1995; 74(3): 494-501. DOI: https://doi.org/10.3382/ps.0740494

Shabani S, Seidavi A, Asadpour L, Corazzin M. Effects of physical form of diet and intensity and duration of feed restriction on the growth performance, blood variables, microbial flora, immunity, and carcass and organ characteristics of broiler chickens. Livest Sci 2015; 180: 150-157. DOI: https://doi.org/10.1016/j.livsci.2015.07.006

Taschetto D, Vieira SL, Angel R, Favero A, Cruz RA. Responses of Cobb $\times$ Cobb 500 slow feathering broilers to feeding programs with increasing amino acid densities. Livest Sci 2012; 146(2-3): 183-188. DOI: https://doi.org/10.1016/j.livsci.2012.03.013 
Tůmová E, Teimouri,A. (2010). Fat deposition in the broiler chicken: a review. Sci Agr Bohem, 2010; 41(2): 121-128.

Wilson PN, Osbourn DF. Compensatory growth after undernutrition in mammals and birds. Biol Rev 1960; 35(3): 325-3633. DOI: https://doi.org/10.1111/j.1469-185X.1960. $\underline{\text { tb01327.x }}$
Yu MW, Robinson FE. The application of shortterm feed restriction to broiler chicken production; a review. J App Poult Res 1992; 1(1): 147-153. DOI: https://doi.org/10.1093/japr/1.1.147

Zubair AK, Leeson S. Compensatory growth in the broiler chicken: a review. World's Poult Sci 1996; 52(2): 189-201. DOI: https://doi.org/10.1079/WPS19960015 